\title{
The Holocene stratified screes from Sierra de Albarracín (Iberian Ranges, Spain) and their paleoenvironmental significance
}

\author{
José L Peña Monné,' Augusto Pérez Alberti, ${ }^{2}$ \\ María M Sampietro Vattuone, ${ }^{3}$ Xose L Otero, ${ }^{4}$ \\ Miguel Sánchez Fabre' and Luis A Longares Aladrén'
}

\begin{abstract}
The most important stratified screes of the lberian Range are found in Sierra de Albarracín. These slope deposits have been traditionally considered, without absolute datings, as having been formed during various Pleistocene cold phases. The aim of this paper is to establish the sedimentological, morphological, chronological, and paleoenvironmental characteristics of these deposits through the study of four profiles recorded in the Calomarde canyon (EI Rollo, El Molino, and Royuela) and Toril. The most representative profile is that of El Rollo as it is formed by basal tufa and stratified scree layers separated by paleosoils. Radiocarbon datings obtained from paleosoil samples show that the sequence ranges between the early and middle Holocene. The profiles from El Molino and Royuela, as well as the upper levels of Toril, complete the sequence showing deposits from upper Holocene (Bronze Age and 'Little Ice Age'). These data show the oscillations during the Holocene between colder phases, represented by the stratified screes, and warmer-wetter phases with soil development and local tufa deposits. This geomorphological and pedological response to the Holocene climatic variability shows its clearest records in the canyons. However, there are almost no Pleistocene accumulations - with the exception of that of Toril (minimum age of $<43.5 \mathrm{ka} \mathrm{BP}$ ). The possibility of relating this succession of Holocene environmental changes to known regional and global climatic stages converts these accumulations into the most important Holocene paleoenvironmental record from the Iberian Ranges and the most complete sequence of Holocene stratified screes from the Mediterranean area.
\end{abstract}

\section{Keywords}

Bronze Age, Holocene, Iberian Ranges, LIA, paleoenvironments, paleosoil, periglacial, tufa

Received 6 July 20I7; revised manuscript accepted 25 July 2017

\section{Introduction}

Stratified screes (or stratified slope deposits) are present in several areas of the mountains of the Mediterranean area and are also described in other places around the world. They are also called grèzes litées, éboulis ordonnées, or éboulis stratifiés in French and derrubios estratificados in Spanish. Their characteristics vary according to the parent material, the degree and kind of stratification they develop, the processes involved into their formation, as well as the depositional environment. However, they have a similar disposition related to the layer gradient, thickness, stratification, alternation of different structures, and clast sizes that make them easily identifiable. These deposits show a regular alternation of layers of coarse clasts with an open work fabric (up to $25 \mathrm{~mm}$, with a mode of ca. $2.5 \mathrm{~mm}$ ) alternated with matrix-supported levels of fine grains, where a sandy loam matrix is dominant $(<0.5$ $\mathrm{mm}$ ), together with small-sized gravels. These deposits can reach several meters thick, but the individual units are between 2 and 25 $\mathrm{cm}$. The deposition layer used to have a gradient of between $12^{\circ}$ and $16^{\circ}$ (Van Steijn, 2011) and perhaps even higher. The papers about this type of sedimentary formation were abundant during the 1990s. Especially important are those of Cailleux (1948), Guillien (1951, 1962), Journaux (1974), Van Steijn et al. (1984), Dewolf (1987), Francou (1990), Bertran et al. (1992), Ozouf et al. (1995), Hetu et al. (1995), Van Steijn et al. (1995), Bertran et al.
(1995), Pappalardo (1999), and Gengnian et al. (1999), among others. However, in more recent decades, interest in this subject has diminished and articles focusing on stratified scree slopes are scarce (De Blasio and Saeter, 2009; García Ruíz et al., 2001; Peña Monné et al., 1998; Pérez Alberti, 2012; Pérez Alberti and Cunha, 2016; Texier and Meireles, 2003).

Since the first publication of Guillien (1951), the origin of stratified scree slope deposits was associated with periglacial

\footnotetext{
'Departamento de Geografía y Ordenación del Territorio and IUCA, Universidad de Zaragoza, Spain

2Departamento de Xeografía, Universidade de Santiago de Compostela, Spain

${ }^{3}$ Laboratorio de Geoarqueología, Universidad Nacional de Tucumán - CONICET, Argentina

${ }^{4}$ Departamento de Edafoloxía e Química Agrícola, Universidade de Santiago de Compostela, Spain
}

\section{Corresponding author:}

María M Sampietro Vattuone, Laboratorio de Geoarqueología, Universidad Nacional de Tucumán - CONICET, España 2903, 4000 San Miguel de Tucumán, Argentina.

Email: sampietro@tucbbs.com.ar 
environments where gelifraction is common in scarcely vegetated places and where slope wash is frequent because of the snow melts. Tricart (1967) added to these factors the freezethaw cycles that facilitate the microgelifraction and movement of materials along the slope. The inner structure of alternating layers was related by some authors to different sedimentary processes (Dylik, 1967; Guillien, 1951; Journaux, 1976); others proposed that their formation is because of a granulometric segregation produced during sedimentation (Bertran et al., 1995; Francou, 1990; Nieuwenhuijzen and Van Steijn, 1990; Van Steijn, 2011).

In the NE of Spain, stratified scree slope deposits were described between 250 and $1600 \mathrm{~m}$ a.s.1. On the Spanish side of the Pyrenees, the first studies on stratified screes were made by Serrat (1977), Martí Bono (1978), Soutadé (1980), Peña Monné (1983), and Chueca et al. (1994), among others. Later, the first radiocarbon datings of this type of deposit from the Aragonian pre-Pyrenean region were published. All showed datings of around the Last Glacial Maximum and the early Holocene ( $9040 \pm 100$ to $22,800 \pm 200$ BP (García Ruíz et al., 2001); $9650 \pm 156$ to $20,060 \pm 180$ BP (Peña Monné et al., 1998)). Stratified screes located at lower altitudes were identified in the Ebro Depression at Valmadrid (250 m a.s.1.) and reported an age of 17,100 $\pm 85 \mathrm{BP}$ (Valero et al., 2004). In the Iberian Ranges, there were several observations collected in geomorphological studies related to this type of deposit, especially in the eastern section, such as the Sierra de Javalambre (Calvo et al., 1983; Gutiérrez and Peña Monné, 1975) and Sierra de Gúdar-Maestrazgo (Ginés and Mateu, 1977; Lozano, 1993; Pailhé, 1984; Simón et al., 1983), or the Upper Tajo (González Amuchastegui and González Martín, 1990). In another mountainous area, Sierra de Albarracín, where this study focuses, Peña Monné and Jiménez (1993) described the presence of two stages of stratified scree deposits (Peña Monné et al., 2000, 2010).

In this paper, several accumulations of stratified screes located in the scarps of limestone reliefs from the Sierra de Albarracín are analyzed - specifically, those formed in the inner section of a fluvio-karstic canyon. The objective of the paper is to provide a detailed analysis together with the chronological dating of the successive stages of the deposit formation. The presence of interbedded paleosoils, as well as tufas related to the formation of the deposit, provides data about the Holocene paleoenvironmental evolution of the Eastern Iberian Range.

\section{Study area}

The Sierra de Albarracín is one of the mountainous sets of the Iberian Range, located on the SE of the province of Teruel (Spain) (Figure 1). Paleozoic quartzites and shales (Figure 1) compose the nucleus of these ranges and form the highest hills in the area (Caimodorro, $1920 \mathrm{~m}$ ). These old massifs are bordered by sandstones of the Lower Triassic, and especially carbonated formations of the Jurassic and Cretaceous periods, the latter in the southern sector of the area and folded by the Alpine pulsations. During the Tertiary, extensive erosion flattened the Mesozoic units forming the 'fundamental erosion surface of the Iberian Range' (Peña Monné et al., 1984) with 1500-1800 m a.s.l. These structures and lithologies favored karstic processes with the development of exokarstic landforms (doline fields and poljes) that enable the absorption of water from the endokarstic system (Peña Monné et al., 2010; Sánchez Fabre et al., 2010). The fluvial network of the Guadalaviar (or Turia), Cabriel, and Tajo Rivers was incised over these flattened surfaces generating deep fluvio-karstic canyons with meandering shapes (Figure 1).
Other important landforms of the Sierra de Albarracín are those formed under cold environments. These morphologies could be grouped according to two structural-lithological environments. On one side, the slopes of the Paleozoic reliefs developed, and on the other side, the fluvio-karstic canyons incised on Mesozoic limestones. The first group includes the Paleozoic massif of Tremedal-Loma Alta where the betterknown periglacial landforms are found (Gutiérrez and Peña Monné, 1977). In several valleys that cut the area, it is possible to identify block slopes and block streams covering most of the slopes, and at the bottom and middle and lower sections of these structures, it is possible to see gelifluction lobes. Over the terraced deposits linked to these landforms, peatbogs developed, and some are still active (González-Sampériz et al., 2006-2007; Menéndez and Esteras, 1965). Peña Monné et al. (2000) also found, in an exceptional position and orientation, a rock glacier and a small glacier moraine at about $1600 \mathrm{~m}$ a.s.1., at the foot of the quartzite scarps of the Tremedal Hermitage. Stratified screes are dominant with dolostones and limestones in calcareous canyons. These are partially covered by functional talus screes in several places. Mechanical cuts made for the extraction of materials for road constructions enable direct observation of the stratified screes otherwise invisible from the surface.

The present climate is Continental Mediterranean Medium Mountain. The average annual temperature is about $9-10^{\circ} \mathrm{C}$ with very cold winters. Average rainfalls are around 550-600 mm, reaching $1000 \mathrm{~mm}$ in the southern area, where the altitude is above $1700 \mathrm{~m}$. Summers are dry and precipitations are usually highly irregular from one year to the next. The resulting semiarid environment includes sabines (Juniperus thurifera, Juniperus sabina) and junipers (Juniperus communis), which together with scrubs and steep formations develop over limestones. Only Paleozoic substrates, Triassic sandstones, and wetter limestone areas are occupied by dense pinewoods that are replanted for forest exploitation. However, in the canyons, the environment remains wet even in summer, favored by the regulation of the karstic system, the steep walls, and the meandering shape of the valley where many areas are usually shaded.

\section{Methodology}

Geomorphological maps of the Sierra de Albarracín and Calomarde canyon were made to locate the main geomorphic features. These were made with 1:30,000 scale aerial photographs (Vuelo Regional de Aragón, 2006), Google Earth images (2013), and fieldwork. A slope map was made using LAS files from LIDAR with $2 \mathrm{~m}$ of pixel resolution (Instituto Geográfico Nacional); this map was used as a base for the geomorphological map. Four representative profiles containing stratified screes were taken as sampling units, and most were mechanically exposed for the construction of a road. The profiles were described according to their stratigraphy and considering all features of chronological and environmental value. Samples for radiocarbon dating were sent to Beta Analytic (Miami, US). The results were calibrated using OxCal v.4.3.

A general characterization of soil samples was also performed. The $\mathrm{pH}$ was analyzed in water at a soil-to-water ratio of 1:2.5 and electrical conductivity (EC) at a soil-to-water ratio of 1:5 (Buurman et al., 1996). Grain size composition was determined by the Robinson pipette method (Buurman et al., 1996). Total carbon (TC) content was measured in a Leco CHN-1000 analyzer. To estimate the total inorganic carbon (TIC) content, the organic carbon was eliminated by combustion for $4 \mathrm{~h}$ at $450^{\circ} \mathrm{C}$ (Cambardella et al., 2001) and the TC content was then determined and defined as TIC. The total organic carbon (TOC) was estimated as the difference between 

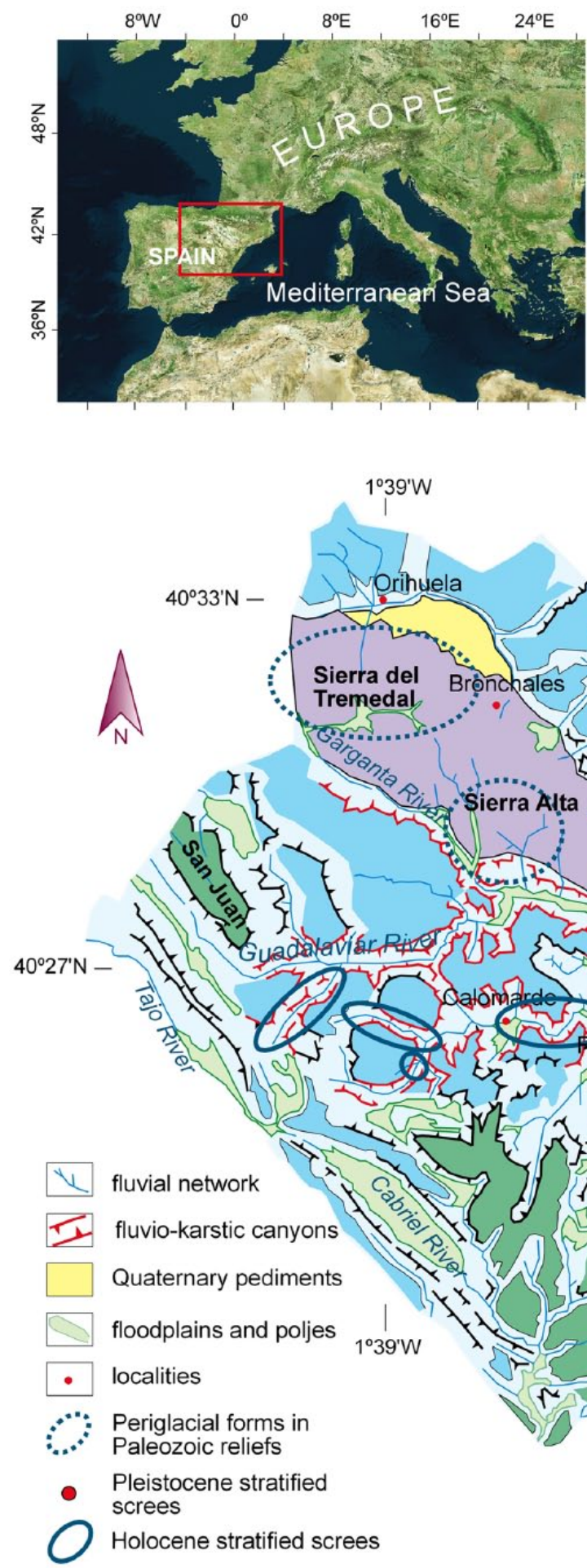

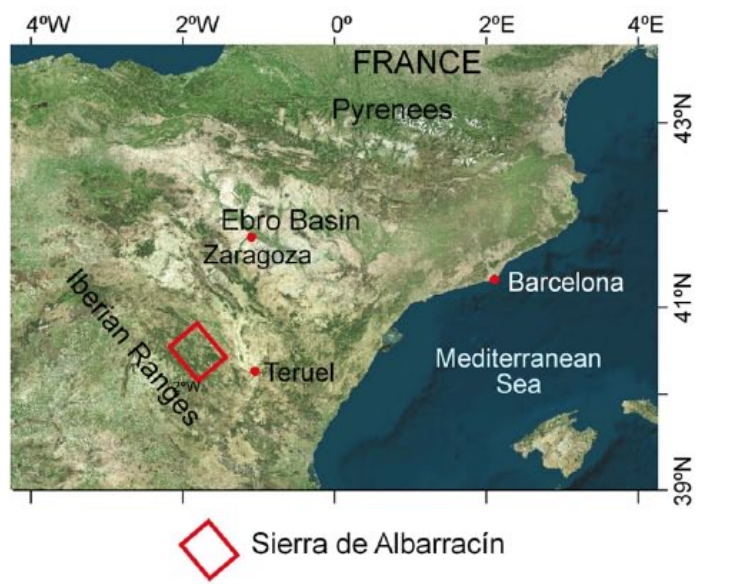

Sierra de Albarracin

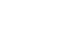



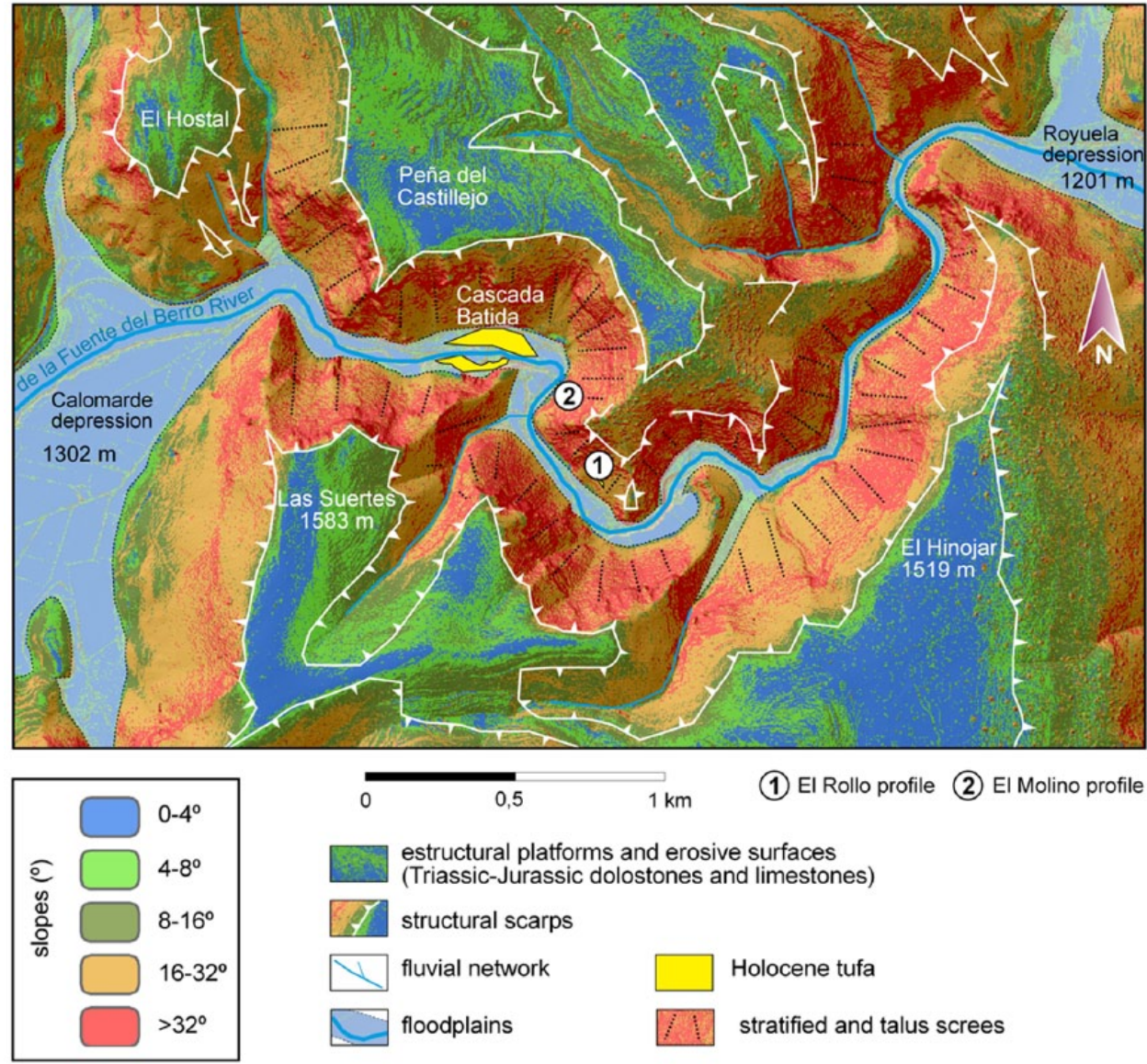

0

$0,5 \quad 1 \mathrm{~km}$

(1) El Rollo profile (2) El Molino profile

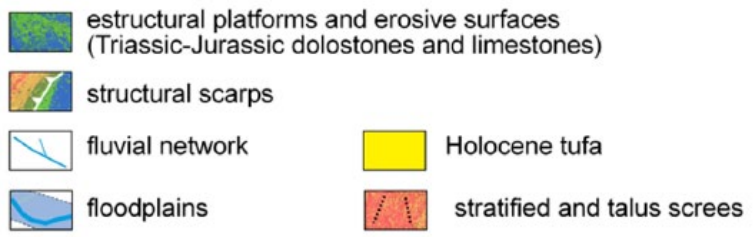

Figure 2. Geomorphological map of Calomarde canyon over a slope map (\%). Stratified screes and talus screes are coincident with the higher gradient values.

river bed. For this reason, they were considered to be Pleistocene deposits (Peña Monné et al., 2010). To confirm their chronology, two samples were taken in the Toril profile for radiocarbon dating (TORIL0001 and TORIL0002) but reported ages older than the sensitivity of the method, so we only have a minimum age that could be extended to other similar outcrops. The second group is much more extensive in the canyons of the range and gray in color - with a yellowish coloration in some places. This group used to be more clastic and less thick and compacted. The longitudinal profiles and gradients show that they are related to a base level closer to the present river level. Until now, they have been considered as a landform developed at the end of the Last Glacial Maximum (Peña Monné and Jiménez, 1993). These deposits only became visible after the excavations of the road-building teams and they rapidly collapsed, and so it is difficult to find good exposed sequences open for long periods.

In the valley of de la Fuente del Berro River (Calomarde canyon), it was possible to locate three main outcrops - each with complimentary information - that enabled us to establish a general sequence with absolute datings, while the Toril profile was situated in the SE of the range (Figure 1).

\section{El Rollo profile (Calomarde canyon)}

The Calomarde canyon is located between the Calomarde and Royuela erosive depressions (Figure 2). It runs from west to east and has a longitude of $4.5 \mathrm{~km}$. It is traversed by the de la Fuente del Berro River, which has an embedded meandering shape (Figure 2). The limestones and dolostones of the Liassic develop sharp escarpments $250-300 \mathrm{~m}$ above the river floodplain. At the feet of these scarps, it is possible to see the development of talus with gradients of between $25^{\circ}$ and $30^{\circ}$ (Figure 2). These slopes, even those with vegetation, are partially covered with screes, and this is clearly visible against the calcareous scarp. The width of the canyon between the scarps is around $600 \mathrm{~m}$, and so in some locations direct sunlight does not arrive at the bottom and the environment remains wetter than the upland calcareous erosive surfaces. The analyzed slope is located at the bottom of the canyon; it is possible to see wide outcrops of tufa (Figure 2), especially at the Cascada Batida. These outcrops were analyzed by Peña Monné et al. (1994), Meléndez et al. (1996), Jiménez et al. (1992-1996), Sancho et al. (1997, 2010), and more recently by Peña Monné et al. (2014) in correlation with other tufa records of the Iberian Range.

The analyzed slope is in the central section of the canyon, at the concave section of a meander. A thick deposit of material is visible because of the excavation works. The upper and lateral detrital layers of the stratified scree deposit were intensively exploited, but it is still possible to observe the stratigraphy. The general picture shows a central accumulation that thins at the margins (Figure 3a). The medium size of the clast diameters is about $3-4 \mathrm{~cm}$ and some disperse blocks reach $25-30 \mathrm{~cm}$. In the central section, it is possible to see a 4-m-high tufa outcrop. The carbonates of the tufa are well stratified forming a continuous scarp $22 \mathrm{~m}$ long. The excavator machinery barely broke the layer, and so some of its geomorphological features, developed before fossilization, remain visible. It is possible to observe that it was a rock shelter with a basal cavity and fallen blocks to the front.

The profile of Figure $4 \mathrm{a}$ shows the main stratigraphic and geomorphological units. In the lower section, there are the remains of an old clastic scree formation - the movements made by the machines left loose debris in the front that hinders observation. Above, it is possible to see the first levels of 


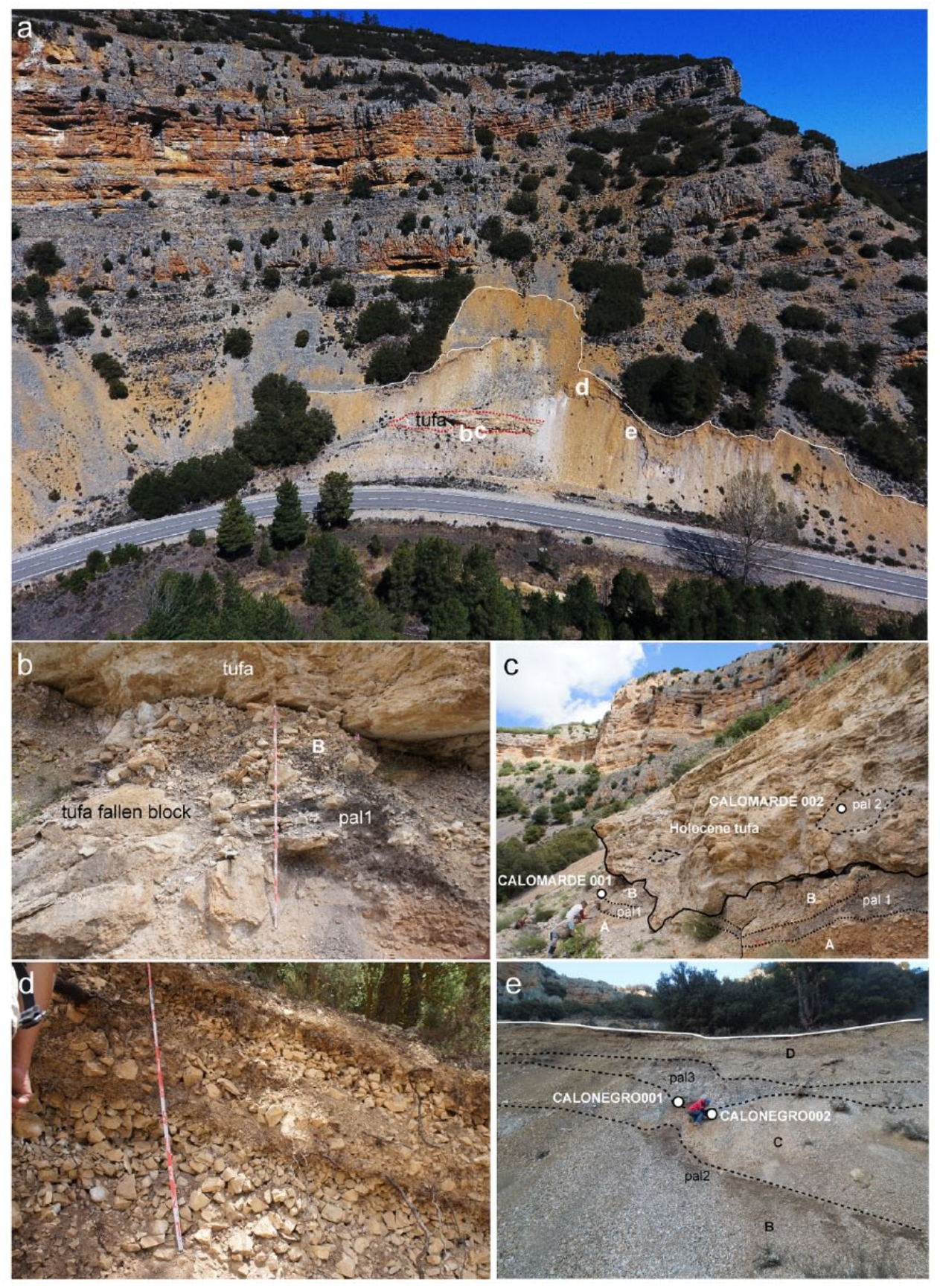

Figure 3. El Rollo images, Calomarde canyon: (a) general view of the upper Triassic-lower Jurassic limestone and dolostone scarp and general slope profile; (b) paleosoil pall and stratified scree B in the limestone rock shelter; (c) tufa scarp and location of A and B units, pall and pal2 paleosoils, and radiocarbon datings; (d) inner view of the stratified scree layers; (e) B, C, and D units, pal2 and pal3 paleosoils, and radiocarbon datings.

stratified screes forming a layer of limestone and dolostone clasts together with some fragments of the tufa with a clayey matrix (A and B stratified scree units). The layers and clasts are overlapped with an opposing gradient that forms a layer oriented to the north which enters under the limestone ledge (Figure 3b). A paleosoil (pal1) dated to 9409-9033 cal. BP (CALOMARDE001) is interbedded between these two units (Figures 3c, 4b, and 5). This paleosoil is a polycyclic soil with a well-developed $\mathrm{Ab}$ horizon (A mollic). It is $30 \mathrm{~cm}$ thick with a $\mathrm{pH}$ of $8.5, \mathrm{Ca} / \mathrm{Mg}$ carbonates $(\mathrm{CIT}=8.6 \%)$, low conductivity $\left(\mathrm{CE}=165 \mu \mathrm{S} \mathrm{cm}^{-1}\right)$, and reveals a lack of salts. The most interesting paleogenetic feature is the addition of organic matter darkening its color (10YR5/2, grayish brown) in comparison with the parent material (Table 1). An enrichment of phosphorous was also detected (PT). A second and deeper A horizon was identified $(2 \mathrm{Ab})$ that was separated from the previous one by a line of gravel showing the existence of a short period of instability. The $2 \mathrm{Ab}$ horizon shows similar composition and properties as the previous one (Table 1). Finally, the parent material located at the base of the soil (2C) shows scarce aggregation, a low content of organic matter, and a much lighter color (10YR7/6, yellow). It was not possible to find abrupt textural changes among the different horizons, and finer fractions (silt and clay) are dominant over the sands.

The next unit is formed by the tufas. These carbonate accumulations are part of the tufa formations of the de la Fuente del Berro-Guadalaviar River described by Peña Monné et al. (1994), Meléndez et al. (1996), and Sancho et al. (1997). Adjoining the tufa scarp and inside several holes, there is another preserved paleosoil (pal2) dated to 8544-9379 cal. BP (CALOMARDE 002). On this paleosoil, it is possible to identify an A horizon with similar features and composition to the previous horizon followed 


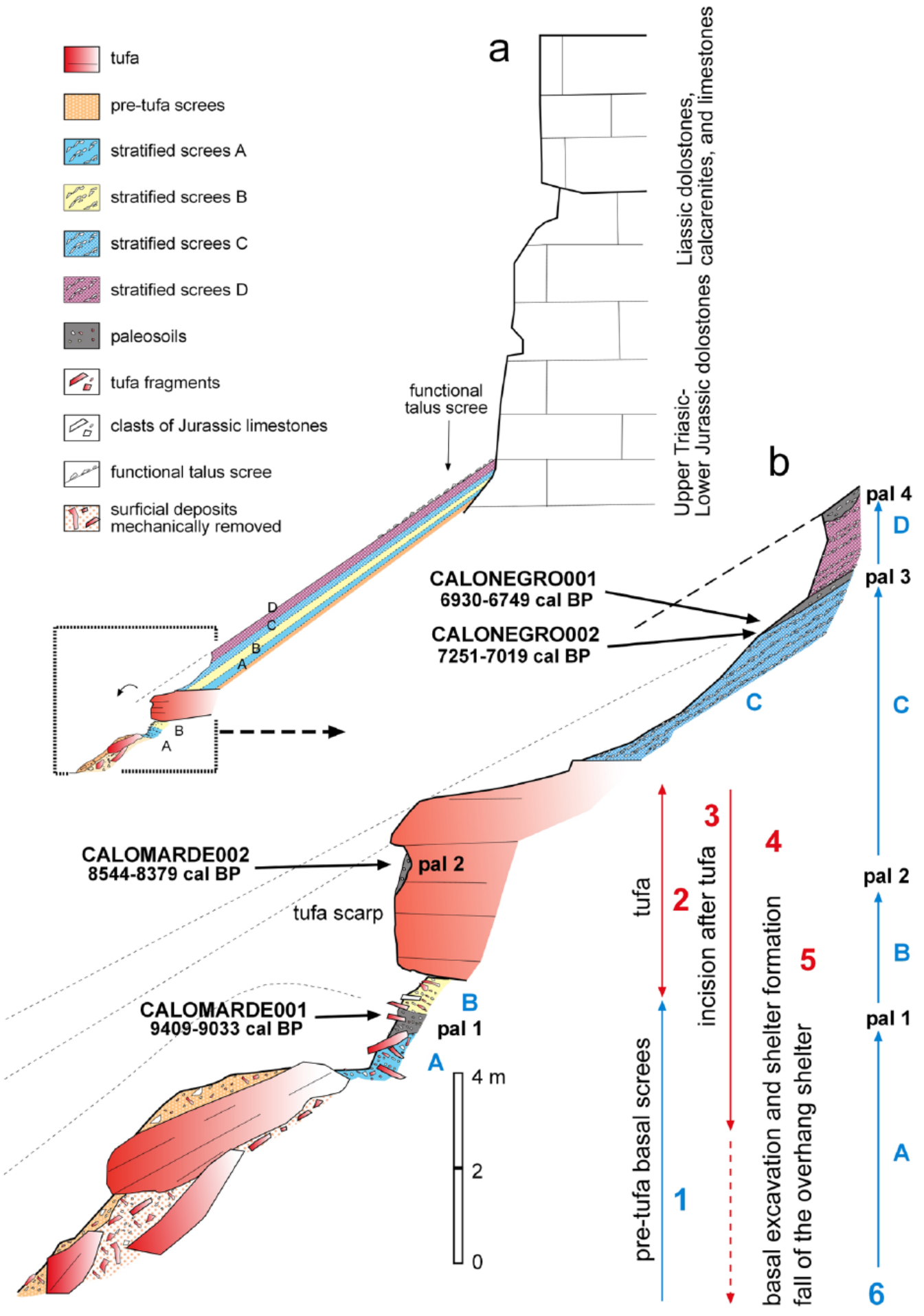

Figure 4. El Rollo profile: (a) general profile showing the unit location and (b) detailed profile showing the tufa, different units, paleosoils, and radiocarbon ages. Bottom right evolutionary geomorphological stages reconstructed for the formation of the profile units.

by an $\mathrm{AC}$ transition horizon with lightly higher content of COT than the $\mathrm{C}$ horizon. Its color is also a little darker (AC: 7,5YR6/4, light brown; C: 10YR6/4, very light brown).

Two other stratified scree layers (C and D) were identified lying above the tufa. They are formed by homometrical clasts with different inner structures such as open matrix, matrixsupported, and clast-supported (Figure 3d). An interbedded paleosoil (pal3) located between these units was dated to 7251-7019 cal. BP (CALONEGRO001) and 6930-6794 cal. BP (CALONEGRO002; Figures 3e, 4b, and 5). This paleosoil shows a profile $\mathrm{A} / \mathrm{C}$, where the $\mathrm{A}$ horizon is $26 \mathrm{~cm}$ thick and has a high COT content. Other properties are similar to that previously described.
Finally, the paleosoil pal4 lies on the top of the profile (Figure $4 b)$ with some functional screes above. Pal4 is a polycyclic paleosoil formed by three edaphic cycles. The uppermost is the present soil and it has an A horizon with high organic matter content $(\mathrm{COT}=6.9 \%)$. Another horizon $\mathrm{A}(2 \mathrm{~A})$ is underneath, but above a $3 \mathrm{~A}$ horizon, and both have less COT content but are similar to those from previous paleosoils.

\section{El Molino profile (Calomarde canyon)}

Very close to the previous location, there is another accumulation of stratified screes also located at the foot of the limestone scarps of the Calomarde canyon. At present, it is possible to just see the upper 3 
Table I. Composition and physico-chemical characteristics of the El Rollo (Calomarde canyon) paleosoils.

\begin{tabular}{|c|c|c|c|c|c|c|c|c|c|c|c|}
\hline \multirow[t]{2}{*}{ Paleosoil } & \multirow{2}{*}{$\begin{array}{l}\text { Pedologic } \\
\text { horizon }\end{array}$} & \multirow[t]{2}{*}{ Soil color } & \multirow[t]{2}{*}{$\mathrm{pH}$} & \multirow[t]{2}{*}{$\mathrm{EC}(\mu \mathrm{S} \mathrm{cm}-1)$} & \multirow[t]{2}{*}{ Total P (mg kg-1) } & $\mathrm{TC}$ & $\mathrm{TIC}$ & TOC & Clay & Silt & Sand \\
\hline & & & & & & \multicolumn{6}{|l|}{$\%$} \\
\hline \multirow[t]{3}{*}{ Pall } & $A$ & Grayish brown (I0YR5/2) & 8.5 & 165 & 261 & 11.6 & 8.6 & 3.1 & 28 & 32 & 40 \\
\hline & $2 A$ & Grayish brown (IOYR4/2) & 8.4 & 332 & 214 & 10.5 & 8.1 & 2.4 & 25 & 34 & 42 \\
\hline & C & Yellow (IOYR7/6) & 9.0 & 88 & 137 & 8.7 & 8.2 & 0.5 & 20 & 33 & 47 \\
\hline \multirow[t]{3}{*}{ Pal2 } & $A$ & Light brownish gray (IOYR6/2) & 8.5 & 232 & 173 & 11.3 & 8.6 & 2.7 & 39 & 30 & 31 \\
\hline & $\mathrm{Cl}$ & Very pale brown (IOYR8/4) & 8.6 & 105 & 170 & 8.8 & 7.6 & 1.9 & 32 & 31 & 37 \\
\hline & $\mathrm{C} 2$ & Very pale brown (IOYR8/4) & 8.6 & 109 & 168 & 9.6 & 8.4 & 1.2 & 37 & 30 & 33 \\
\hline Pal3 & A & Grayish brown (IOYR5/2) & 8.6 & 228 & 376 & 10.8 & 7.4 & 3.4 & 32 & 41 & 27 \\
\hline \multirow[t]{3}{*}{ Pal4 } & $\mathrm{Ah}$ & Dark yellowish brown (IOYR3/4) & 8.3 & 190 & 301 & 14.2 & 7.3 & 6.9 & 29 & 30 & 41 \\
\hline & $2 \mathrm{~A}$ & Dark yellowish brown (IOYR4/6) & 8.7 & 141 & 309 & 10.0 & 7.1 & 2.9 & 33 & 33 & 34 \\
\hline & $3 \mathrm{~A}$ & Dark yellowish brown (IOYR4/6) & 8.8 & 124 & 284 & 10.9 & 8.6 & 2.4 & 26 & 19 & 55 \\
\hline
\end{tabular}

EC: electrical conductivity;TC: total carbon;TIC: total inorganic carbon;TOC: total organic carbon.

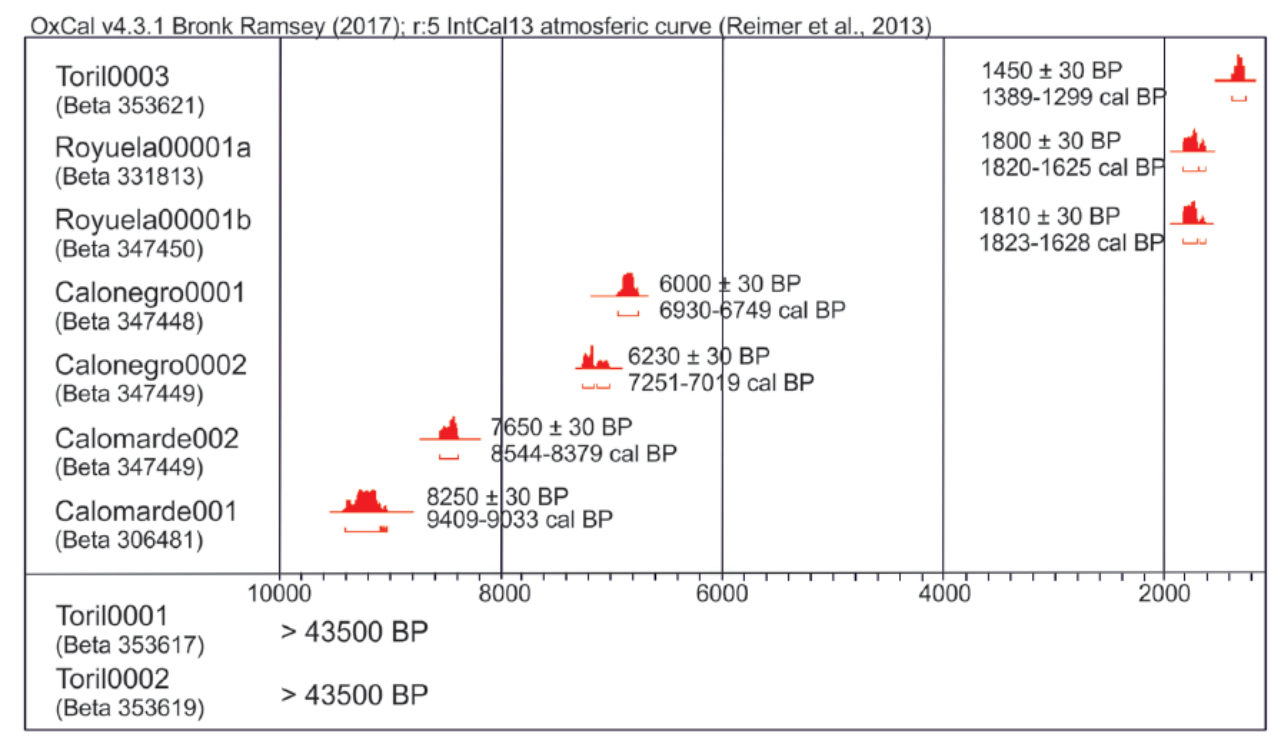

Figure 5. Radiocarbon datings obtained from the paleosoils of the stratified screes of Sierra de Albarracín ordered by ages.

$\mathrm{m}$ (Figure 6a). It is composed of layers of well-stratified angular clasts of dolostones and limestones. It presents an open work fabric with carbonate encased layers and layers enriched with clays with lighter colors and a matrix-supported structure. Some darker layers probably relate to the upper paleosoils of the El Rollo profile, but their organic matter content was insufficient for radiocarbon dating. Figure $6 \mathrm{~b}$ shows the middle section of the profile before being buried by the movement of the upper materials of the slope. It is possible to observe the cyclic repetition of layers of $0.4-0.6 \mathrm{~m}$ with open work fabric interbedded with carbonated hardened layers. It can be seen that the accumulation contains a general array of layers which thicken further down the slope (Figure 6a). This feature was impossible to see at El Rollo due to the orientation of the profile. Another interesting feature is that the gradient of the present slope is different from that of the inner layers of the deposit $\left(28-35^{\circ}\right)$. The layers of stratified screes are cut in the middle section by a soft slope surface $\left(20-25^{\circ}\right)$ with an edaphic level extended through the river and a thin layer of sediments. The lower section of this slope is irregular and some Bronze Age ceramic fragments (ca. 3500-1700 BP) were recovered. It has the shape of a regularized ramp and is repeated in several places of the Sierra de Albarracín.

\section{Royuela stratified screes}

The next studied profile is around $6 \mathrm{~km}$ to the west of the other profiles, following the de la Fuente del Berro River and at the crossing of the Royuela and Calomarde roads. It is possible to see just the upper layers of the deposit formed by angular stratified gravels separated by finer layers and with organic matter and charcoals. Some of these charcoals were dated to 1820-1625 cal. BP (ROYUELA00001A; Figures 5 and 6d). As the results were so young, another sample was taken from another point of the same layer and dated to 1823-1628 cal. BP (ROYUELA00001B; Figures 5 and 6c).

\section{Toril stratified screes}

Close to Toril, and to the south of previous profiles, another stratified scree can be seen that has a 13-m-thick deposit and is around $300 \mathrm{~m}$ long (Figure 6d). Most of the profile corresponds to 'ancient' and is composed of a sequence of seven stratified screes with interbedded paleosoils (P1-P7 levels in Figure 6d; Table 2). It was possible to collect some charcoals from one of the clastic sequences (sequence 3,2 m above the base of the profile) and from the paleosoil located in the upper section of the profile $(5 \mathrm{~m}$ above the base). Two radiocarbon datings were made giving two minimum dates $(<43,500 \mathrm{BP}$; TORIL0001 and TORIL0002; Figure 5). These datings prove that these layers belong to a cold Pleistocene stage established before the development of the other sequences dated. However, there is a younger section at the top (P8 and P9 levels; Figure 6d) with a paleosoil containing many charcoal fragments dated to 1389-1299 cal. BP (TORIL0003; Figure 5). This is the youngest result so far found in these ranges. 

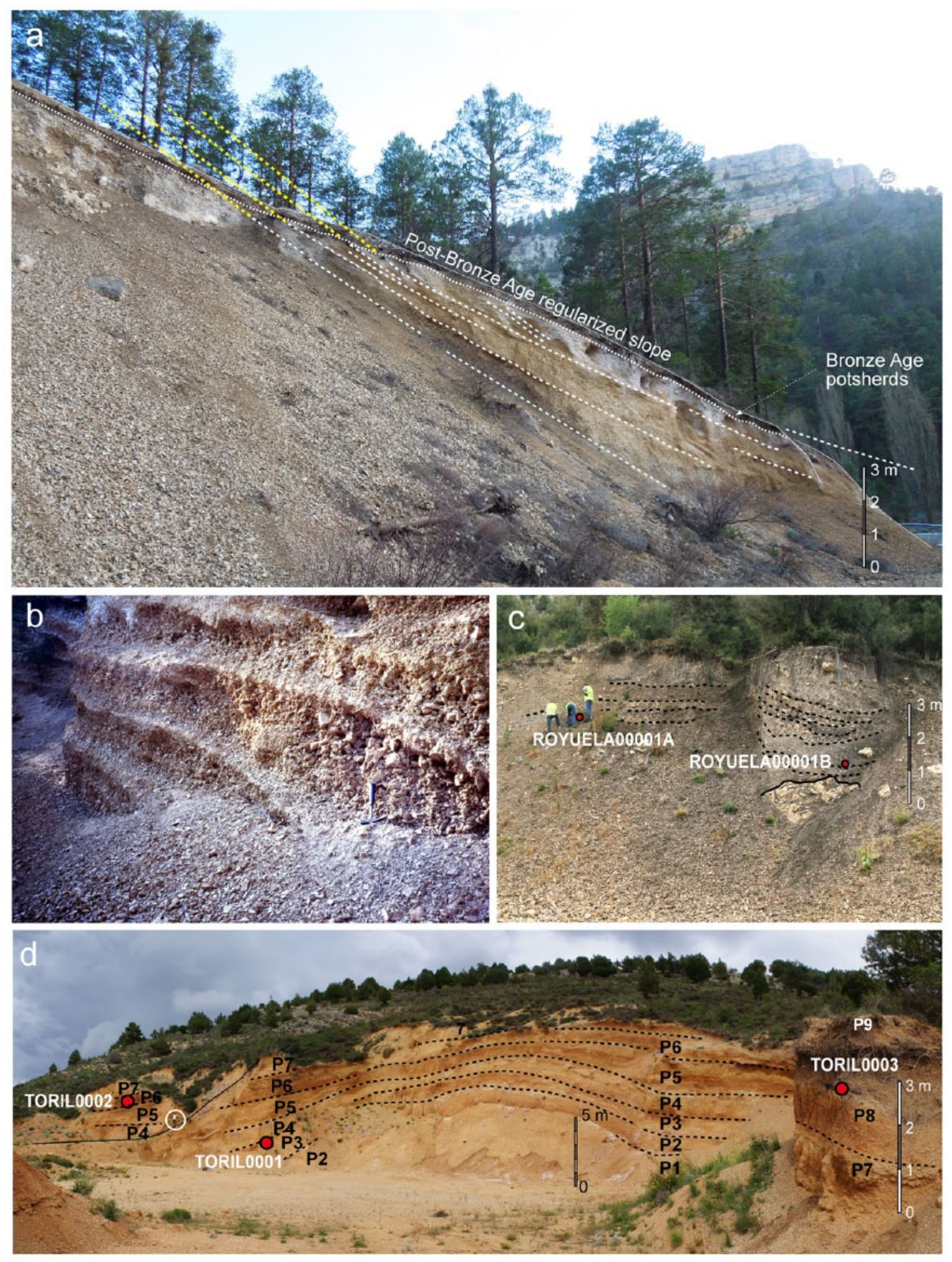

Figure 6. (a) Stratified screes of El Molino (Calomarde canyon); the scree stratification is cut by the regularization profile of the post-Bronze slope; (b) detail of the stratification of El Molino profile; (c) stratified scree, soils, and radiocarbon datings of Royuela profile; (d) general view of Pleistocene stratified screes (levels PI-P7) of Toril profile; see the change in color of the Holocene deposits (the circle highlights a person as scale).TORIL000I and TORIL0002 points are dated <43,500 BP.The sample TORIL0003 to the roof of level P8 dates the upper Holocene's most recent soil.

The Pleistocene stratified screes displayed a greater complexity in the soil-forming processes than the El Rollo profile. No edaphic horizon was identified in the first level (P1), and only a crust formed by precipitates of secondary $\mathrm{Ca} / \mathrm{Mg}$ was identified. Several poorly developed transitional horizons (BC) identified at level P2 were differentiated from the parent material by a more developed structure, aggregation, and a red color (Table 2) because of a slight increase in the concentration of clay (illuvial clay) relative to the parent material. Levels P3, P4, and P5 showed paleosoils characterized by a clearly illuvial accumulation of clay in some of their horizons (Bt), and secondary carbonates (Btk, Bk) confer an overall red color (red: 2,5YR4/6; Table 2). The accumulation of illuvial clay was also revealed by the in situ observation of clay coatings lining the surfaces of pores and particles. The paleosoils of the upper levels (P6, P7, P8, and P9) are characterized by organic matter accumulations, indicating the presence of an A or AC horizon, which was further confirmed by a substantial increase in the TOC content (Table 2) that gave the soil a darker color (brown: 7,5YR4/4; 7,5YR3/3).

\section{Discussion}

As pointed by Oliva et al. (2016) in a review about periglacial processes and landforms in the Iberian Peninsula, the geomorphological evidences about the Holocene cold processes are 'related to rock glaciers and solifluction, as well as other processes for which no age control exists (i.e. talus scree)'. In the Sierra de Albarracín, we have enough information to establish an evolutionary paleoenvironmental reconstruction using the geomorphological interpretation, the interbedded paleosoils, and the tufa (that also appear in other points of the Sierra de Albarracín) and the chronological data. 
Table 2. Composition and physico-chemical characteristics of the Toril paleosoils.

\begin{tabular}{|c|c|c|c|c|c|c|c|c|c|c|}
\hline \multirow{2}{*}{$\begin{array}{l}\text { Sedimentary } \\
\text { level }\end{array}$} & \multirow[t]{2}{*}{ Description } & \multirow[t]{2}{*}{ Soil color } & \multirow[t]{2}{*}{$\mathrm{pH}$} & \multirow[t]{2}{*}{$\mathrm{EC}(\mu \mathrm{S} \mathrm{cm}-1)$} & $\mathrm{TC}$ & $\mathrm{TIC}$ & TOC & Clay & Silt & Sand \\
\hline & & & & & \multicolumn{6}{|l|}{$\%$} \\
\hline \multirow[t]{2}{*}{ PI } & Horizon C (no paleosoil) & Very pale brown (IOYR8/2) & 8.5 & 104 & 8.1 & 7.6 & 0.5 & 16 & 37 & 53 \\
\hline & Crust (Ca/Mg precipitate) & Very pale brown (IOYR8/2) & 8.9 & 77 & 12.1 & 11.5 & 0.6 & 12 & 54 & 35 \\
\hline \multirow[t]{4}{*}{ P2 } & Horizon $\mathrm{BCkl}$ & Reddish yellow (5YR7/6) & 8.8 & 89 & 7.6 & 7.3 & 0.4 & 20 & 29 & 51 \\
\hline & Horizon BCk2 & Reddish yellow (5YR6/6) & 8.7 & 90 & 6.7 & 6.3 & 0.3 & 22 & 28 & 50 \\
\hline & Horizon $\mathrm{BCk} 3$ & Yellowish red (5YR5/8) & 8.7 & 98 & 4.7 & 4.4 & 0.2 & 34 & 23 & 43 \\
\hline & Horizon $\mathrm{C}$ with $\mathrm{Ca} / \mathrm{Mg}$ precipitate & Pink (5YR7/4) & 9.0 & 78 & 9.4 & 8.9 & 0.5 & 17 & 24 & 59 \\
\hline \multirow[t]{3}{*}{ P3 } & Horizon $\mathrm{Bt}$ & $\operatorname{Red}(2,5 Y R 4 / 6)$ & 8.7 & 109 & 0.8 & 0.7 & 0.2 & 69 & 11 & 20 \\
\hline & Horizon CBtk & $\operatorname{Red}(2,5 Y R 4 / 6)$ & 8.8 & 118 & 2.6 & 2.3 & 0.3 & 59 & 15 & 26 \\
\hline & Horizon Ck & Reddish yellow (5YR6/8) & 8.8 & 94 & 5.8 & 5.5 & 0.2 & 28 & 31 & 41 \\
\hline P4 & Horizon $\mathrm{Bt}$ & Reddish yellow (5YR6/6) & 8.7 & 73 & 0.3 & 0.1 & 0.2 & 87 & 7 & 6 \\
\hline \multirow[t]{2}{*}{ P5 } & Horizon CBI & Reddish yellow (7,5YR6/8) & 8.8 & 89 & 3.9 & 3.4 & 0.5 & 31 & 28 & 42 \\
\hline & Horizon Bt & $\operatorname{Red}(2,5 Y R 4 / 6)$ & 8.9 & 105 & 2.7 & 2.2 & 0.52 & 55 & 21 & 24 \\
\hline P6 & Horizon A & Brown (7,5YR4/4) & 8.6 & 159 & 5.0 & 3.4 & 1.7 & 41 & 38 & 21 \\
\hline P7 & Horizon A & Dark brown (7,5YR3/3) & 8.4 & 195 & 6.0 & 3.1 & 2.9 & 37 & 32 & 31 \\
\hline P8 & Horizon AC & Brown (7,5YR4/4) & 8.8 & 148 & 5.0 & 3.0 & 2.0 & 40 & 30 & 30 \\
\hline \multirow[t]{2}{*}{ P9 } & Horizon A (actual soil) & Brown $(7,5 Y R 3 / 3)$ & 8.3 & 148 & 7.6 & 3.4 & 4.2 & 34 & 29 & 37 \\
\hline & Horizon C & Brown (7,5YR5/4) & 8.7 & 129 & 7.5 & 6.7 & 0.8 & 28 & 25 & 47 \\
\hline
\end{tabular}

EC: electrical conductivity;TC: total carbon;TIC: total inorganic carbon;TOC: total organic carbon.

The 'ancient' stratified screes, which are little known in the region, were assumed to be Pleistocene because of their stratigraphic position in relation to the $+24 \mathrm{~m}$ river terrace of the Guadalaviar River (Entrambasaguas profile; Peña Monné and Jiménez, 1993). The two datings of $>43.5 \mathrm{ka}$ BP obtained at Toril reinforce that these deposits are Pleistocene and relatively old. New datings, with more adequate methods, will be necessary to precisely define their ages. Between these ages and the older stratified screes of the Sierra de Albarracín, there is a wide temporal gap without regional paleoenvironmental information. Cold phases from the Iberian Peninsula, with significant glacial records, as important as the Older Dryas (17.5-14.5 $\mathrm{ka}$; Palacios et al., 2016) and the Younger Dryas (12.9-11.7 ka; García-Ruiz et al., 2016), do not have records in the slopes of these valleys.

The early Holocene is represented by the El Rollo profile, located in the middle of the Calomarde canyon. The profile interpretation reaches some complexity given the position of some of its units, but this could be solved with geomorphological criteria, as shown in Figure 7a and b. In a first step, the tufas (2) were sediment over old stratified screes (1). The carbonate accumulation fills the bottom of the valley forming part of a stepped system of cascades and dams. There are some fragments of this in the margins of the valley, and this highlights the accumulation of the Cascada Batida falls, which are the remains of a large edifice in retreat (Meléndez et al. 1996; Peña Monné et al., 1994; Sancho et al., 1997). After the deposition of the tufas, an incision stage started (3) (Figure 7a), leaving the tufa layer disconnected from the system. During this period, a cavity was excavated under the tufa by basal erosion of the layer (4) (Figure 7b). The remains of this rock shelter lay as large broken blocks in front of the tufa scarp (5) (Figure 7c) and fossilized by the stratified screes later deposited (6A). These latter deposits adapted to this irregular topography. In the beginning of the deposition, the cavity that formed under the tufa was filled by higher level screes (6A) that covered the sector above the tufa, as well as the slope, and part of the material sediment remains inside the cavity under the tufa. For this reason, the gradient of the layers formed at this point is contrary to the general slope gradient and the sediments are mixed with tufa fragments (Figures $3 b$ and $7 d$ ). This stage of stratified screes is temporally interrupted by a stable phase followed by a biostatic period ( $>100$ years) that favored the development of a deep A horizon with high organic matter content (pal1) dated to 9409-9033 cal. BP. This dating indicates that in the tufas (2), the processes of morphological individualization $(3,4,5)$ and the A stratified screes must have developed before these dates. From the paleoenvironmental point of view of the North Atlantic and Greenland records (Figure 8), the stratified scree A (in which soil is dated to 9409-9033 cal. BP) could correspond to the cold event 9.5 of Bond et al. (1997) and the cold event 9.3 of the NGRIP curve of Rasmussen et al. (2007). Besides, the tufas could be chronologically located between the cold events 10.3 and 9.5 of Bond et al. (1997), equivalent to the 9.95 and 9.3 events of Rasmussen et al. (2007) because they were dated to $10100 \pm 0.3 \mathrm{BP}$ with U/Th downstream (Sancho et al., 1997). González Amuchastegui and González Martín (1990) described other stratified screes, related to the tufa accumulations, in the upper valley of the Tajo River, without datings that enable a chronological correlation.

A new process of accumulation of stratified scree $6 \mathrm{~B}$ then finished the fill of the cavity under the tufa and covered the tufa scarp until the establishment of a new stable period that enabled the formation of a new paleosoil (pal2) dated to 8544-8379 cal. BP (Figure 7e). It is probable that during these times the upper part of the tufa scarp was still visible at the surface. The obtained datings of this phase are coincident with the tempered-wet phase during which the tufas of Cascada Batida were formed (U/Th: $8000 \pm 0.7$ BP; Sancho et al., 1997), as well as others in the Iberian Range (Peña Monné et al., 2014). The stratified screes (6B) over which the soil was formed belonged to a previous cold phase.

The $6 \mathrm{C}$ level shows the reactivation of the stratified scree formation process that totally covered the tufa scarp and deposited after pal3 dated to 6749-7251 cal. BP (Figure 7f). These datings are coincident with a warm period considering the GISP curve (Alley, 2000) after a cold phase dated around 7100-7300 BP. These latter dates could correspond to the accumulation of the $6 \mathrm{C}$ stratified scree (accurate data is unavailable). El Rollo profile has another stratified scree level (6D) (Figure $7 \mathrm{~g}$ ) that finishes with the formation of a polycyclic soil (pal4).

Unfortunately, we lack absolute datings for more environmental data. According to the regional archaeological data, around 7500-7000 BP, the Neolithic technological transformation started, under more template temperatures (Alday et al., in preparation). This environment seems to be stable until the late 

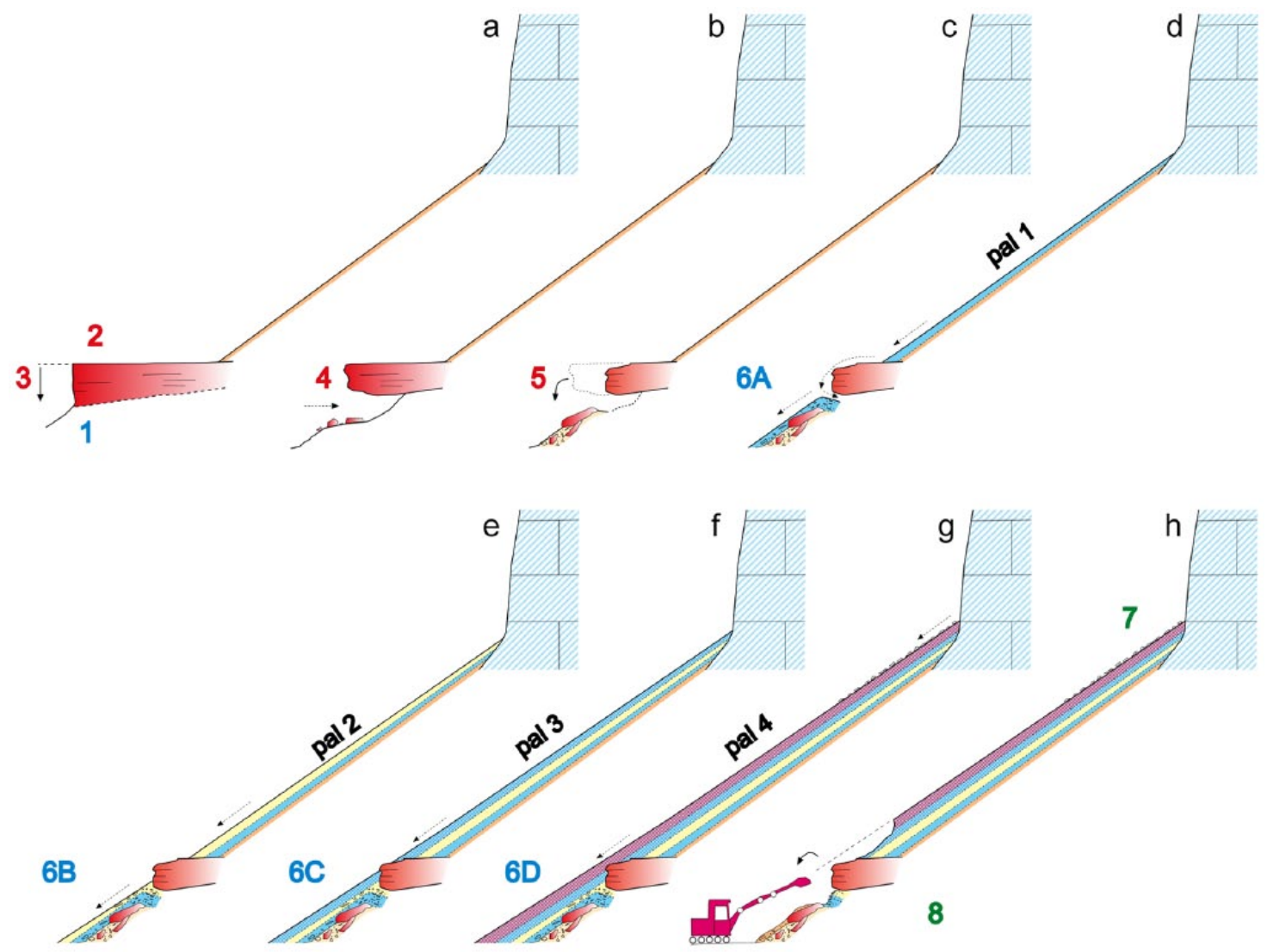

Figure 7. Evolutionary reconstruction of the El Rollo stages: $(a-c)$ geomorphological evolution prior to described stratified screes: I, before tufa deposits; 2 , tufa accumulation; 3 , fluvial incision; 4 , rock shelter formation in the base of the tufa scarp; $(\mathrm{d}-\mathrm{g})$ accumulation stages of the stratified screes (6A-6D) and development of the interbedded paleosoils (pall-pal4); (h) recent superficial screes (7); mechanical excavation of present profile (8).

Chalcolithic with high aridity records around 4200 cal. BP followed by wetter conditions during the Bronze and Iron Ages (Pérez-Lambán et al., 2014).

The topography and gradient preserved in the areas where the machines did not excavate enable us to see the impact of the regularization processes that affected the deposit after its stabilization, with little changes visible when comparing the inner gradient and the final slope. This is particularly noticeable in the profile of El Molino (Figure 6a). At this point, the layers of the stratified scree are cut by a new slope development with different gradient and formation processes. At El Molino, as well as in several places in the Sierra de Albarracín, Bronze Age ceramic fragments were found included in the slopes. These kinds of morphologies, as well as their environmental meaning, have been analyzed in various geoarchaeological investigations in the Iberian Range (Gutiérrez and Peña Monné, 1998). Their formation was linked to solifluction processes typical in cold and wet environments that favored the generalized regularization of the slopes. These slopes are mainly formed by fine sediments and used to develop thick edaphic horizons. The same geomorphological features were described in the Ebro Depression (Pérez-Lambán et al., 2014). Having potsherds from the Bronze Age (post 1800-750 cal. BP), these landforms are known as the Post-Bronze Age regularized slope, and their formation ended with the Iron Age (750-550 cal. BP). The wet and cold climatic features reflected by this stage are in consonance with the Iron Age Cold Phase (Bond event 2.8, Bond et al., 1997), which marks the transition between the SubBoreal and the Sub-Atlantic period (Figure 8). This represents the first slope morphology of the upper Holocene and is very different to the stratified scree of the previous described phases.

Finally, the last three dates obtained for stratified screes are much more recent. In the case of the Royuela profile, the datings belong to the Roman Warm Period (250 BC to AD 400) and the Late Antique 'Little Ice Age' (LALIA; AD 536-660) for the case of Toril (Büntgen et al., 2016) or Dark Ages Cold Period (DACP; AD 509-565; Helama et al., 2017) equivalent to the 1.4 Bond event (Bond et al., 1997; Figure 8). These data show that the stages of stratified scree formation continued during the relative cold stages of the Sub-Atlantic phase, and its most recent representation, in the present warm period, is the presence of functional screes that cover much of the older stratified screes from previous phases.

From the paleoenvironmental point of view, the fluviokarstic areas of the Sierra de Albarracín suffered during the Holocene a cyclic repetition of two contrasting situations. On one side (Figure 9a), wet and relatively warm conditions permitted the development of soils stabilizing the slopes, which were covered with vegetation and without marked erosive processes. This situation limited the arrival of coarse sediments in the river that favored the formation of stepped cascade-barrage tufas in the bottom valley. In contrast, during drier and colder stages, with less vegetation cover and much more snow and gelifraction processes, the previous equilibrium was broken and this favored the development of stratified screes that added coarser materials to the main rivers (Figure 9b). Under these conditions, tufas entered into destruction phases because of the coarser bottom loads of the rivers.

This kind of contrasted geomorphological response during the Holocene is also present in the Sierra Nevada (Southern Spain), even with other characteristics. On this case, Oliva et al. (2011) identified seven stages with dominance of solifluction processes produced in colder and wetter climate phases alternated with warmer and drier periods during which soils were developed. Therefore, the study of these processes is of great importance for 


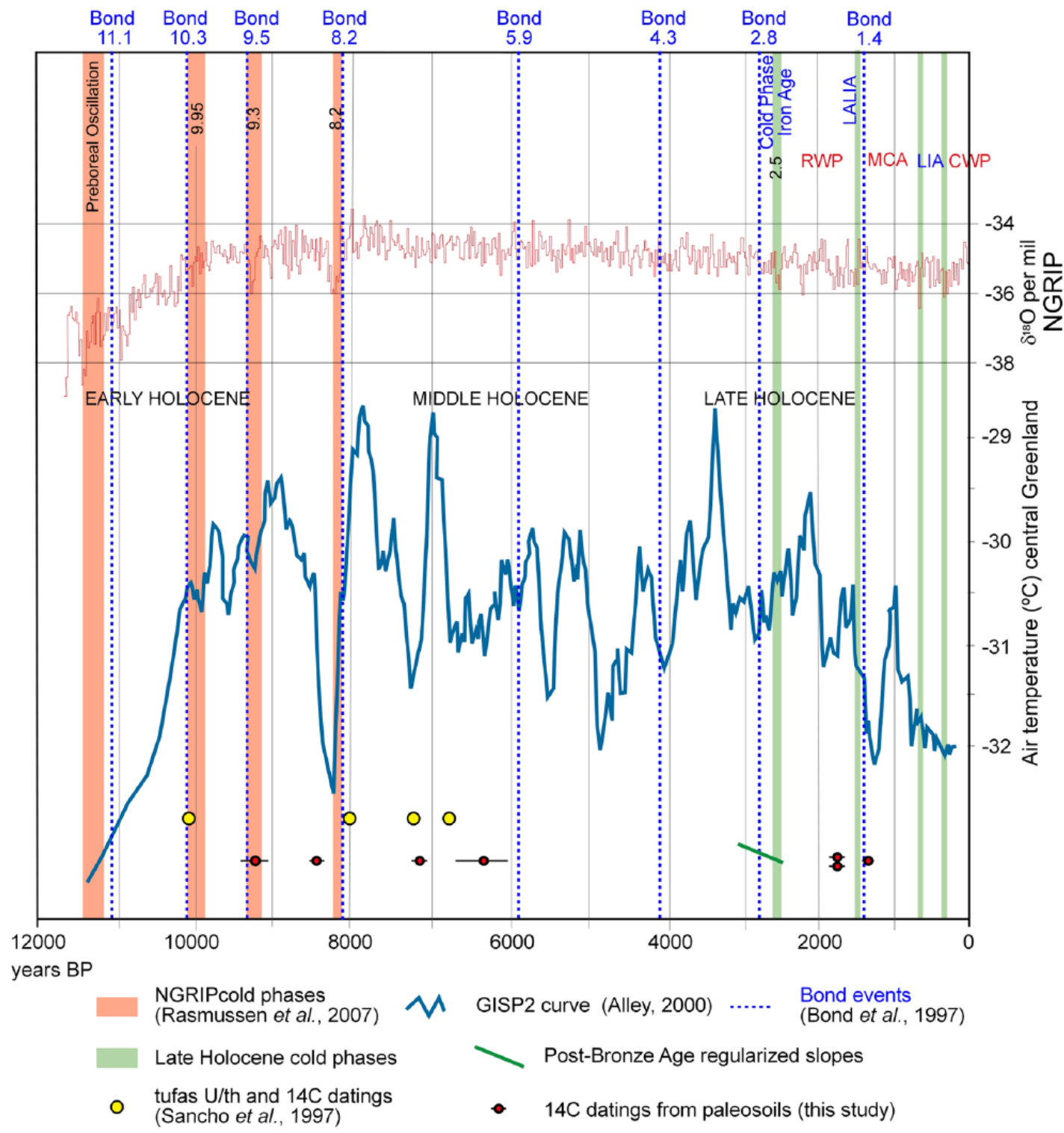

Figure 8. Holocene temperature variations according to Rasmussen et al. (2007) (NGRIP) where the main cold phases were highlighted, GISP2 curve according to Alley (2000), Bond events (Bond et al., 1997), and regional upper Holocene cold phases, paleosoil radiocarbon datings obtained in this study, tufa ages (Sancho et al., 1997), and chronological span of the post-Bronze Age slope regularization.

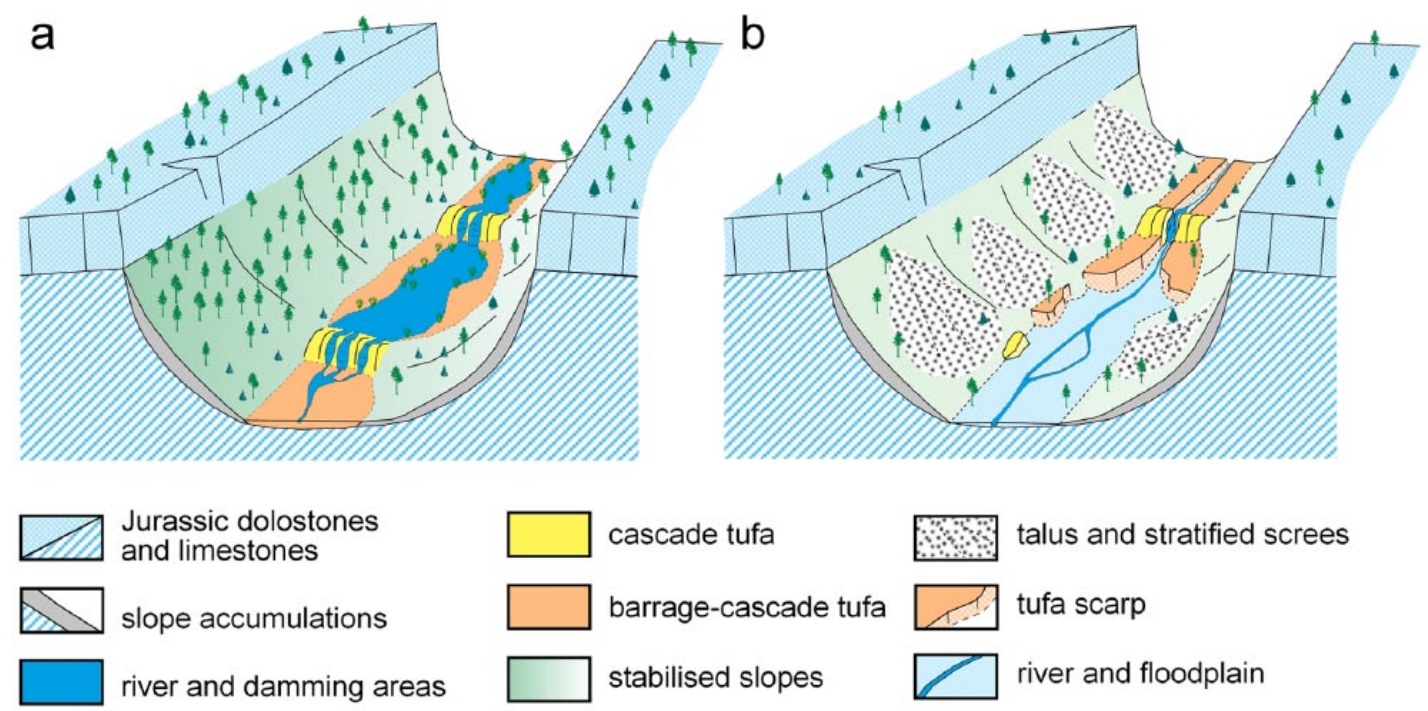

Figure 9. Reconstruction of two geomorphological scenarios during the Holocene evolution of a fluvio-karstic canyon as a consequence of two opposite climatic conditions: (a) warm and wet climate, with stabilized slopes, soil development, and vegetation cover; (b) cold and dry climate, with less vegetation cover, gelifraction, and screes accumulation in the slopes. 
the reconstruction of the Holocene little paleoenviromental fluctuations and their effects over landscape.

\section{Conclusion}

The stratified screes of the Sierra de Albarracín are an excellent example of cold environment landforms, typical of the middle Mediterranean mountains. These slope accumulations are located at the foot of calcareous scarps, mainly in the inner part of fluviokarstic canyons. This study proves that the traditional assignation to Pleistocene cold phases must be revised. Most of the obtained radiocarbon datings gave Holocene results, including recent upper Holocene. Moreover, analysis provides the first chronological data about the Holocene environmental changes in the Iberian Range.

The four profiles selected were chronologically complementary. The most relevant is the El Rollo profile (at Calomarde Canyon) because of the different layers of stratified screes, as well as the interbedded paleosoils. These soils have enough organic matter to provide a chronologically accurate framework. According to our reconstruction, the early and middle Holocene are represented by a cyclic succession of four stratified scree stages (A-D) with high environmental instability in the slopes, representing cold and dry conditions. In between, there were more stable climatic phases with soil development (pal1-4). Some tufa outcrops are also identifiable on this profile, and other points of the valley and this point to warmer and wetter environmental phases.

The radiocarbon datings obtained from the paleosoils of another two profiles (Royuela and Toril) gave information about their formation during the Roman Warm Period and the 1.4 Bond event. At the El Molino profile, it is possible to identify the development of a slope formed after the Bronze Age (a much generalized stage across the NE of Spain). During that period, the climate was wet and cold, and the period is related to the cold phase of the Iron Age.

This study constitutes a significant example of the construction of an evolutionary paleoenvironmental model based on periglacial geomorphological features and soil development. The sequences recorded in the Sierra de Albarracín gave the first datings of Holocene stratified screes in the Iberian Ranges and show the importance of paleoenvironmental record conservation in the inner sectors of the deep karstic canyons.

\section{Acknowledgements}

This work is a contribution of the Quaternary Paleoenvironments Research Group (PALEOQ; Aragon Government and European Regional Development Fund). The authors acknowledge the logistic support of Antonio Jiménez Martínez (Fundación Santa María de Albarracín).

\section{Funding}

The authors acknowledge the economic support of the Instituto de Estudios Turolenses (DiputaciónProvincial de Teruel).

\section{References}

Alday A, Domingo Martínez R, Sebastián M et al. (in preparation) The silence of the layers. Archaeological sites visibility in the Pleistocene-Holocene transition at the Ebro Basin. Quaternary Science Reviews.

Alley RB (2000) The Younger Dryas cold interval as viewed from central Greenland. Quaternary Science Review 19: 213-226.

Bertran P, Coutard JP, Francou B et al. (1992) Données nouvelles sur l'origene du litage des grèzes: Implications paléoclimatiques. Geographie Physique et Quaternaire 46: 97-112.

Bertran P, Coutard JP, Francou B et al. (1995) Dépôts de pente calcaires du nord de l'Aquitanie. Répartition stratigraphique et géographique des facies. Zeitschrift Für Geomorphologie NF 39: 29-54.
Bond G, Showers W, Cheseby M et al. (1997) A pervasive millennial-scale cycle in north Atlantic Holocene and glacial climates. Science 278: 1257-1266.

Bowman RA (1988) A rapid method to determine total phosphorus in soils. Soil Science Society of America Journal 52: 1301-1304.

Büntgen U, Myglan VS, Ljungqvist FC et al. (2016) Cooling and societal change during the Late Antique Little Ice Age from 536 to around 660 AD. Nature Geoscience 9: 231-236.

Buurman P, Van Lagen B and Velthorst EJ (1996) Manual for Soil and Water Analysis. Leiden: Backhuys Publishers.

Cailleux A (1948) Etudes de Cryopedologie. Paris: CDU.

Calvo A, Gutiérrez M, Peña JL et al. (1983) Morfología de vertientes y neotectónica en el Macizo de Javalambre (Provincia de Teruel). Cadernos do Laboratorio Xeolóxico de Laxe 5: 429-448.

Cambardella CA, Gajda AM, Doran JW et al. (2001) Estimation of particulate and total organic matter by weight loss-on-ignition. In: Lal R, Kimble JM, Follett RF et al. (eds) Assessment Methods for Soil Carbon. Boca Raton, FL: Lewis Publishers, pp. 349-359.

Chueca J, Gómez-Ortia A, Lampre F et al. (1994) El periglaciarimso heredado y actual de la Cordillera Pirenaica y del Sietama Costero Catalán. In: Gómez-Ortiz A and Salvador F (eds) Periglaciarismo en la Península Ibérica, Canarias y Baleares. Granada: Universidad de Granada, pp. 93-117.

De Blasio FV and Saeter MB (2009) Small-scale experimental simulation of talus evolution. Earth Surface Processes and Landforms 34(12): 1685-1692.

Dewolf Y (1987) Dépôts de pente stratifiés. In: Comité National Français De Géographie (ed.) Notes et Comtes-rendus du Groupe de Travail: Régionalisation du Périglaciaire. pp. 19-39.

Dylik J (1967) Solifluxion, congelifluxion and related slope processes. Geografiska Annaler 49: 167-177.

Francou B (1990) Stratification mechanisms in slope deposits in high subequatorial mountains. Permafrost and Periglacial Processes 1: 249-263.

García Ruíz JM, Valero-Garcés B, González-Sampériz P et al. (eds) (2001) Stratified scree in the central Spanish pyrenees: Palaeoenvironmental implications. Permafrost and Periglacial Processes 12: 233-242.

García-Ruiz JM, Palacios D, González-Sampériz P et al. (2016) Mountain glacier evolution in the Iberian Peninsula during the Younger Dryas. Quaternary Science Reviews 138: $16-30$.

Gengnian L, Zhijiu C and Daokai Yongqiu W (1999) The stratified slope deposits at Kunlunshan Pass, Tibet Plateau, China. Permafrost and Periglacial Processes 10: 369-375.

Ginés A and Mateu J (1977) Fenómenos de clima frío en el Alt Maestrat. Actas. II Reunión Nacional Grupo Esp. Trab. Cuaternario, Trabajos Neógeno-Cuaternario 6: 93-103.

González Amuchastegui M and González Martín JA (1990) Derrubios crioclásticos y etapas frías en el área de Molina de Aragón (Guadalajara). In: Gutierrez M, Peña JL and Lozano V (eds) Actas I Reunión Nacional de Geomorfología, Teruel, 8-12 September 1990, pp. 169-178.

González-Sampériz P, Valero B, Moreno A et al. (2006-2007) Aportación al conocimiento de los paleoambientes cuaternarios del Macizo del Tremedal (Sierra de Albarracín, Teruel). Teruel 91: 7-25.

Guillien Y (1951) Les grèzes litées de Charente. Revue Géographique des Pyrénees et du Sud-ouest 22: 153-162.

Guillien Y (1962) Grave, Grèze, Gress. Bulletin de l'Association de Géographes Français 303-304: 79-81.

Gutiérrez M and Peña Monné JL (1975) Karst y periglaciarismo en la Sierra de Javalambre (provincia de Teruel). Boletín Geológico y Minero 86: 561-572. 
Gutiérrez M and Peña Monné JL (1977) Las acumulaciones periglaciares del Macizo del Tremedal (Sierra de Albarracín). Boletín Geológico y Minero 88: 109-115.

Gutiérrez M and Peña Monné JL (1998) Geomorphology and Late-Holocene climatic change in Northeastern Spain. Geomorphology 23: 205-217.

Helama S, Jones PD and Briffa KR (2017) Dark Ages Cold Period: A literature review and directions for future research. The Holocene 1: 7.

Hetu B, Van Steijn H and Bertran P (1995) Le rôle des coulées de pierres sèches dans la genèse d'un certain type d'éboulies stratifiés. Permafrost and Periglacial Processes 6: 173-194.

Jiménez A, Meléndez A, Peña Monné JL et al. (1992-1996) Estudio de las formaciones travertínicas de la cuenca del Río Guadalaviar (Sierra de Albarracín, provincia de Teruel). Teruel 34: 83-84.

Journaux A (1976) Les grèzes du Châtillonnais. Bulletin de l'Association Française pour l'Étude du Quaternaire 4849:123-138.

Lozano MV (1993) El modelado de las laderas de las sierras de Gúdar (Cadena Ibérica Oriental, provincia de Teruel). In: Instituto Tecnológico Geominero de España (ed.) El Cuaternario en España y Portugal. Madrid: ITGE-AEQUA, pp. 861-868.

Martí Bono CE (1978) Aspectos de la problemática geomorfológica del Alto Aragón Occidental. Estudios Geográficos 153: 473-493.

Meléndez A, Peña Monné JL and Sancho C (1996) Factores fisicoquímicos que intervienen en el desarrollo de las barreras tobáceas bioconstruidas del río de la Fuente del Berro (Sierra de Albarracín, Teruel). Revista de la Sociedad Geológica de España 9: 125-134.

Menéndez J and Esteras M (1965) Análisis polínico de la turbera de los 'Ojos del Tremedal' (Orihuela del Tremedal, Teruel). Teruel 34: 191-198.

Nieuwenhuijzen ME and Van Steijn H (1990) Alpine debris flows and their sedimentary properties. A case study from the French Alps. Permafrost and Periglacial Processes 1: 111-128.

Oliva M, Schulte L and Gómez Ortiz A (2011) The role of aridification in constraining the elevation range of Holocene solifluction processes and associated landforms in the periglacial belt of the Sierra Nevada (Southern Spain). Earth Surface Processes and Landforms 36: 1279-1291.

Oliva M, Serrano E, Gómez Ortiz A et al. (2016) Spatial and temporal variability of periglaciation of the Iberian Peninsula. Quaternary Science Reviews 137: 176-199.

Ozouf JC, Coutard JP and Lautridou P (1995) Grèzes, Grèzes litées: Historique des Definitions. Permafrost and Periglacial Processes 6: 85-87.

Pailhé P (1984) La Chaîne Ibérique Orientale. Etude Géomorphologique. $\mathrm{PhD}$ Thesis, Université de Bordeaux.

Palacios D, Andrés N, Gómez-Ortiz A et al. (2016) Evidence of glacial activity during the Oldest Dryas in the mountains of Spain. In: Hughes PD and Woodward JC (eds) Quaternary Glaciation in the Mediterranean Mountains. London: Geological Society of London (Special Publications 433), pp. 87-110.

Pappalardo M (1999) Observations on stratified slope deposits, Gesso Valley, Italian Maritime Alps. Permafrost and Periglacial Processes 10: 107-111.

Peña Monné JL (1983) La Conca de Tremp y Sierras Prepirenaicas comprendidas entre los ríos Segre y Noguera Ribagorzana: Estudio geomorfológico. Lleida: Instituto de Estudios Ilerdenses.

Peña Monné JL and Jiménez A (1993) El modelado de laderas en el curso medio del río Guadalaviar (Sierra de Albarracín, prov. de Teruel). In: Instituto Tecnológico Geominero de España (ed.) El Cuaternario de España y Portugal. pp. 129-34.
Peña Monné JL, Chueca J and Julián A (1998) Los derrubios estratificados del sector central pirenaico: Cronología y límites altitudinales. In: Gómez Ortiz A, Salvador F, Schulte L et al. (eds) Procesos Biofisicos Actuales en Ambientes Fríos. Barcelona: Universitat de Barcelona, pp. 205-216.

Peña Monné JL, Gutiérrez M, Ibáñez MJ et al. (1984) Geomorfología de la Provincia de Teruel. Teruel: Instituto de Estudios Turolenses.

Peña Monné JL, Lozano MV, Sánchez Fabre M et al. (2000) Las acumulaciones de clima frío de la Sierra de Albarracín en el contexto de la Cordillera Ibérica oriental. In: Peña Monné JL, Sánchez-Fabre M and Lozano MV (eds) Procesos y Formas Periglaciares en la Montaña Mediterránea. Teruel: Instituto de Estudios Turolenses, pp. 127-147.

Peña Monné JL, Lozano MV, Sánchez-Fabre M et al. (2010) Las acumulaciones de clima frío de la Sierra de Albarracín. In: Peña Monné JL, Sánchez-Fabre M and Lozano MV (eds) Las formas del relieve de la Sierra de Albarracín. Teruel: CECAL, pp. 163-188.

Peña Monné JL, Sancho C, Arenas A et al. (2014) Las tobas cuaternarias en el sector aragonés de la Cordillera Ibérica. In: González Martín JA and González Amuchastegui MJ (eds) Las tobas en España. Zaragoza: Sociedad Española de Geomorfología, pp 159-172.

Peña Monné JL, Sancho C, Meléndez A et al. (1994) Las formaciones travertínicas holocenas de la cuenca del río Guadalaviar (Sierra de Albarracín, provincia de Teruel). Aspectos geomorfológicos y paleoclimáticos. In: Arnáez J, García Ruiz JM and Gómez Villar A (eds) Geomorfología en España, pp. 159-172.

Pérez Alberti A (2012) La formación de depósitos estratificados de ladera en un clima frio marítimo (Andes de Tierra del Fuego, Argentina). Nimbus: Revista de Climatología, Meteorología y Paisaje 29: 491-509.

Pérez Alberti A and Cunha PP (2016) The stratified slope deposits of Tierra del Fuego (Argentina) an analogue for similar pleistocene deposits in Galicia (NW Spain). Poligonos. Revista de Geografia 28: 183-209.

Pérez-Lambán F, Peña-Monné JL, Fanlo J et al. (2014) Paleoenvironmental and geoarchaeological reconstruction from lateHolocene slope records (Lower Huerva Valley, Ebro Basin, NE Spain). Quaternary Research 8: 1-14.

Rasmussen SO, Vinther BM, Clausen HB et al. (2007) Early Holocene climate oscillations recorded in three Greenland ice cores. Quaternary Science Reviews 26: 1907-1914.

Sánchez Fabre M, Peña Monné JL, Lozano MV et al. (2010) Los campos de dolinas de la Sierra de Albarracín. In: Peña Monné JL, Sánchez-Fabre M and Lozano MV (eds) Las formas del relieve de la Sierra de Albarracin. Teruel: CECAL, pp. 89-110.

Sancho C, Peña Monné JA and Meléndez A (1997) Controls on Holocene and present-day travertine formation in the Guadalaviar River (Iberian Chain, NE Spain). Z. Fur Geomorphology 41: 289-307.

Sancho C, Meléndez A, Peña Monné JL et al. (2010) Las tobas del río Guadalaviar (Sierra de Albarracín). In: Peña Monné JL, Sánchez-Fabre M and Lozano MV (eds) Las formas del relieve de la Sierra de Albarracin. Teruel: CECAL, pp. 137-161.

Serrat D (1977) Nota sobre unos derrubios estratificados en el Pirineo oriental español. In: Alberdi MT, Gallardo J, Alexandre $\mathrm{T}$ et al. (eds) Actas II Reunión Grupo Español Trabajo del Cuaternario, Jaca 15-20 September 1975, Madrid: CSIC, pp. 275-285.

Simón JL, Pérez Cueva A and Calvo A (1983) Morfogénesis y neotectónica en el sistema de fosas del Maestrat (Castellón). Estudios Geológicos 24: 249-258. 
Soutadé G (1980) Modelé et Dynamique Actuelle des Versants Supra-forestiers des Pyrènées Orientales. Albi: Imprimerie Coopérative du Sud-Ouest.

Texier JP and Meireles J (2003) Relict mountain slope deposits of northern Portugal: Facies, sedimentogenesis and environmental implications. Journal of Quaternary Science 18(2): 133-150.

Tricart J (1967) Le modelé des régions périglaciaires. In: Tricart J and Cailleux A (eds) Traité de Geomorphologie, II. Paris: SEDES.

Valero B, González P, Navas A et al. (2004) Paleohydrological fluctuations and steppe vegetation during the Last Glacial Maximum in the central Ebro valley (NE Spain). Quaternary International 122(1): 43-55.
Van Steijn H (2011) Stratified slope deposits: Periglacial and other processes involved. In: Martini IP, French HM and Pérez Alberti A (eds) Ice-Marginal and Periglacial Processes and Sediments. London: Geological Society of London (Special Publications 354), pp. 213-226.

Van Steijn H, Van Brederode L and Goedheer G (1984) Stratified slope deposits of the grèze-litée type in the Ardeche Region in the South of France. Geografiska Annaler 66: 195-305.

Van Steijn H, Bertran P, Francou B et al. (1995) Models for the genetic and environmental interpretation of stratified slope deposits: Review. Permafrost and Periglacial Processes 6: $125-146$ 